\title{
Practice, Power and Inertia: Personal Narrative, Archives and Dealing with the Past in Northern Ireland
}

Hamber, B., \& Kelly, G. (2016). Practice, Power and Inertia: Personal Narrative, Archives and Dealing with the Past in Northern Ireland. Journal of Human Rights Practice, 8(1), 25-44. https://doi.org/10.1093/jhuman/huw001

Link to publication record in Ulster University Research Portal

\section{Published in:}

Journal of Human Rights Practice

\section{Publication Status:}

Published online: 14/03/2016

DOI:

10.1093/jhuman/huw001

\section{Document Version}

Author Accepted version

\section{General rights}

Copyright for the publications made accessible via Ulster University's Research Portal is retained by the author(s) and / or other copyright owners and it is a condition of accessing these publications that users recognise and abide by the legal requirements associated with these rights.

\section{Take down policy}

The Research Portal is Ulster University's institutional repository that provides access to Ulster's research outputs. Every effort has been made to ensure that content in the Research Portal does not infringe any person's rights, or applicable UK laws. If you discover content in the Research Portal that you believe breaches copyright or violates any law, please contact pure-support@ulster.ac.uk. 


\title{
Practice, Power and Inertia:
}

\section{Personal narrative, archives and dealing with the past in Northern Ireland}

\author{
Brandon Hamber and Grainne Kelly ${ }^{1}$
}

\author{
Published in the Journal of Human Rights Practice (2016) 8 (1): 25-44.
}

Pre-copyedited, author-produced PDF ${ }^{2}$

\begin{abstract}
Through the prism of Northern Ireland, this article explores the function of existing and proposed archives within societies emerging from conflict, and highlights their potential in adding complexity to understanding conflict and challenging dominant narratives. The article outlines how, despite progress since the Northern Ireland peace accord in 1998, efforts to deal with the past and human rights violations have been piecemeal and politically contested. In the absence of a comprehensive approach to the past, testimony gathering, initiated 'unofficially' at a community level, has provided opportunities for individuals' experiences of the conflict to be documented and acknowledged. The recent Stormont House Agreement (2014) seeks to establish an Oral History Archive as a central repository for individuals to 'share experiences and narratives related to the Troubles'. The article discusses the challenges in developing this 'official' archive, and the problem of reconciling competing historical narratives of the past. This is contrasted against the growth in bottomup 'storytelling' or testimony work. The article argues for supplementing the official process with wider testimony gathering processes directed by and located within community contexts. It is argued that the deliberate juxtaposition of contrasting horizontal or intercommunity narratives held by different local parties may allow for the emergence of a more complex and inclusive narrative of the past, rather than at- tempts to impose a shared vertical narrative, which is subject to either further con- testation or uncomfortable compromise.
\end{abstract}

Keywords: archives; dealing with the past; narratives; Northern Ireland; storytelling; testimony

\section{Introduction}

The idea is not to put diverse experiences in a blender and come up with a puttycoloured one which no one ever had, it is the opposite. It is to simply suggest, by housing a wide range of voices and feelings together, that they do exist together,

\footnotetext{
${ }^{1}$ Brandon Hamber (b.hamber@ulster.ac.uk) is the John Hume and Thomas P. O'Neill Chair in Peace at Ulster University, Incore (International Conflict Research Institute) and Honorary Professor at University of the Witwatersrand (Johannesburg) African Centre for Migration and Society. Grainne Kelly (g.kelly@ulster.ac.uk) is a Lecturer at Ulster University, Incore. 2 This is a pre-copyedited, author-produced PDF of an article accepted for publication in Journal of Human Rights Practice following peer review. The version of record Brandon Hamber and Gráinne Kelly (2016). Practice, Power and Inertia: Personal Narrative, Archives and Dealing with the Past in Northern Ireland. Journal of Human Rights Practice (2016) 8 (1): $25-44$ is available online at: http://jhrp.oxfordjournals.org/content/early/2016/03/12/jhuman.huw00.
} 
in the one place. And they can do so without destroying the people who have them. We can allow this to happen. It is not impossible (Gorman, 1994).

In the months following the paramilitary ceasefires of 1994, a local poet and playwright wrote a newspaper article calling for a new conflict archive. In the piece, Damian Gorman argued for the establishment of a centre which would collect and house the testimonies of those who wished to share their experiences and memories on the thirty years of violent conflict in and about Northern Ireland. As the quote above indicates, he did not view this proposal as unproblematic, but sought to challenge the assumption that individual's politically diverse experiences of conflict could not sit alongside one another, while also inferring that the act of placing personal testimonies together could have wider social impacts. Two decades on, this proposal for an oral history archive, focusing on the conflict and its impact, continues to have traction. As a concept, it speaks to wider issues of how societies emerging from conflict value, utilise and contend with the multiple and conflicting narratives of individuals who have suffered political violence. This, we will argue, is particularly pertinent in societies such as Northern Ireland where the public arena is marked by antithetical and competing versions of 'the causes, conduct and meaning of the conflict' (Dawson, 2007: 24). Such competing narratives are embedded in political discourses and present in the mass media, social networks, community rituals and education systems, and are 'structured around the monuments, museums, national, religious and ethnic calendars' (Brown and Ní Aoláin, 2014: 12).

Typically historical narratives ${ }^{3}$ and social discourses are linked to distinctive webs of power and provide the justification for collective (national) belonging and the determination of 'otherness' (Bar-Tal et al., 2014; Ross, 2003). As a result, argues Bar-Tal et al. (2014), strong emotions can become linked to particular historical narratives with which the general population identifies, becoming 'entrenched in them' (663). In this context, changing the embedded narratives becomes a significant challenge. We will argue that, in post-accord peacebuilding processes the sharing of personal testimonies or micro-narratives of conflict can play a particular role in challenging historical narratives and adding complexity to the dominant narratives that have hardened during the course of the conflict.

The peace deal in Northern Ireland, although largely effective in halting violence, has been characterized as an elite-driven agreement that leaves ethnic divisions in place (Brown and Ní Aoláin, 2014: 5) and has done little to facilitate greater levels of social, political and cultural interaction in the intervening period (Nolan, 2014). Narratives are contested not only between citizens and the state, but also between citizen and citizen. Indeed, the entire concept of the 'state' have become increasingly complex, given the consociational powersharing arrangements that established the devolved Northern Ireland Assembly as part of the Good Friday/Belfast Agreement of 1998, and the new political relationships formed between the British and Irish governments on common policy issues.

There are, of course, multiple ways by which dominant narratives of the past can be challenged or changed, including the development of new educational curricula, meaningful inter-communal dialogue and encounter processes, the reinterpretation of historical documentation, and the collection and dissemination of personal testimonies of the conflict (Ross, 2003). It is the latter process that is the focus of this article: specifically the role that

\footnotetext{
${ }^{3}$ According to Bar-Tal, Oren and Nets-Zehngut (2014) the concept 'narrative' refers to 'a story about an event or events that has a plot with a clear starting point and end- point, providing sequential and causal coherence about the world and/or a group's experience'.
} 
individual accounts gathered, and the creation of collective archives to house them, can have in the post-conflict or post-transition period. The article aims to explore how such collections can shape and influence the narratives of the past and help address deep social divisions. It interrogates the motivation of the politically diverse parties to the Northern Ireland Assembly to mutually agree to the 'official' gathering and curating of such testimonies and how this complements, contradicts or challenges the collection of personal narratives at an 'unofficial' community level.

Focusing primarily on the case of Northern Ireland, where former enemies now share devolved power from Westminster, we will argue that competing historical narratives are inevitable. We aim in the article to widen the current emphasis on the value of uncovering state archives for the purpose of pursuing truth and justice beyond the realm of the legal human rights framework (Cardenas, 2010; Ciorciari and Franzblau, 2014; Jelin, 1994), to explore the social and cultural opportunities and challenges that exist in the creation of new archives of personal testimonies within a post-conflict political dispensation, and the role of the a power-sharing 'state' in facilitating such processes.

\section{Testimony and storytelling}

The notion that sharing your story and narrating one's pain in public (either in an official or non-official process) is therapeutic has grown exponentially in recent years (Humphrey, 2002). This is, in part, linked to the turn in individualised western psychological processes as dominant frames of reference for understanding the impact of violations on individuals and assisting personal recovery from atrocity (Hamber, 2009; 2015). The growth in giving testimony has also been linked to the evolving culture of rights internationally, with some arguing that the collection of stories of violation and the development of publicly accessible archives could help cement and consolidate human rights in the present (Jelin, 1994) and ensure non-repetition in the future (Schaffer and Smith, 2004).

There is, however, an ongoing debate as to the relationship between official and unofficial processes of collecting testimonies about the past and the resultant impact. Increasingly testimony-taking has been linked to official transitional justice mechanisms such as truth commissions that have created repositories of such statements, with varying degrees of public accessibility (Jones and Rubli, 2013). This has often happened in parallel to community-based initiatives that operate as unofficial truth commissions, collecting personal accounts of human rights abuse (Bickford, 2007), or seek to elucidate the past through the creation of collections of oral histories from a range of political and social perspectives.

Post-transition South Africa, for example, witnessed the proliferation of community-based organisations which aimed to fill the gap in social memory which apartheid left (Harris, 2002). Some of these processes fed into the formal Truth and Reconciliation Commission (TRC) set up in 1994, but most had a life of their own, gaining greater community ownership and engagement. Some are now more accessible to the public than the truth commission records which are currently difficult to retrieve as they are housed in the state archive (Harris, 2007). While some South African victims felt vindicated by the state-led TRC process and valued the opportunity for their suffering to be acknowledged (Hamber, 2009), community testimony and archive-building processes have remained relevant post-TRC as many victims, dissatisfied with the statement-taking process, had a continued desire to document the human rights violations perpetrated against them. The testimony-taking 
process of the TRC has also been criticized for its violation-specific focus which limits the outlining of the wider causes of suffering (Chapman and Ball, 2007; Mamdani, 2000; Wilson, 2001), which many community-based initiatives can more readily capture.

Bickford's (2007) analysis of civil society-led truth-telling initiatives emphasizes their importance in seeking to 'elucidate, clarify, and acknowledge past human rights abuse or mass atrocity in order to contribute to democratic rule and peace for the long-term' (2007: 994) and argues that, in this regard, they are not dissimilar to formal truth-recovery processes. However, official processes may have a more rigid and limited remit which does not allow for a wider exploration of the impact of conflict beyond issues of justice, accountability and truth which community-based processes oral history can more freely pursue. Pilar RiañoAlcalá and Erin Baines recognize the important space held by community-based processes and note that a more exclusive focus on formal mechanisms can 'lack resonance with the everyday lives of survivors' (2011: 414). It has also been argued that official processes can reinforce a 'new truth' that has little room for alternative views. As Hackett and Rolston note: 'The structures of political transition or settlement can lead to an official story or memory that erases, downplays, marginalizes or formalizes and institutionalizes the stories of some or all victims' (2009: 362) compared to unofficial processes that can produce 'complex and multi-layered accounts' (Hackett and Rolston, 2009: 370). That said, unofficial processes may lack the power to alter the wider political context, provide political acknowledgment and could, in themselves, reinforce limited or narrow community positions. Stevan Weine (2006) warns against the naïve or uncritical assumption that testimony work is both healing and socially transformative, which has led to the creation of 'a cottage industry' of 'not forgetting' (Weine, 2006: 46).

\section{Preservation of records and the archive}

While formal transitional justice processes (such as truth commissions or trials) are now commonplace in the aftermath of gross human rights violations, the preservation of records generated through such processes, and their public accessibility, is 'often underestimated and forgotten'. ${ }^{4}$ The impact of such archives has been considered in terms of their long-term cultural and historical value (Schwartz and Cook, 2002), but there is limited focus on their use as tools for wider social change processes in the post-conflict context. It is only in the last decade or so that scholars have started to inquire as to the role of archives in wider peacebuilding processes and to assert that archives (and the archivist) are not neutral actors but are tied into a web of relationships and political power. As Verne Harris (2002) observes, an archive should be viewed as a dynamic political place, a space that is both a representation of the truth about the past but, at the same time, also in a constant process of contestation, construction and reconstruction. By way of example, Wilson (2001) argues that the main objective of the South African TRC was to consolidate a new national identity and legitimize the incoming state. In this context, it is no wonder that the resultant archive of testimonies has received little attention from the state after the Commission ended, especially as it would continue to unearth stories that might not fit with the broad reconciliation-orientated trajectory of the TRC project.

As Schwartz and Cook (2002) observe, archives are increasingly seen as having both the ability to reinforce social hegemonies and to be sites of resistance. In this context, one might

\footnotetext{
${ }^{4}$ SwissPeace, Archives and Dealing with the Past website, http://archivesproject.swisspeace.ch/aboutus/project-partners/why-this-project/, accessed 26 October 2015.
} 
argue that archives (instigated either through official or unofficial processes), if utilized in particular ways, can re-orientate the moral compass of the society and provide an opportunity to change attitudes and humanize 'the other' (Dawson, 2007).

Within this framework, we will describe the various proposals for the establishment of a central conflict-related archive, based primarily on the collection of new testimonies. We will then outline the development of community-based 'storytelling work' ${ }^{5}$ which has continued prior to, and in parallel to such calls. We will then return to the wider debates about the possibilities which these processes represent, both locally and internationally, before exploring how the politics of power and contestation open up new spaces for understanding the past, as well restricting what may, or may not, be possible.

\section{The Northern Ireland case}

The Belfast or Good Friday Agreement of 1998 provided a roadmap out of conflict and included many features which were future-focused, including the establishment of the devolved, power-sharing Northern Ireland Assembly, the setting up of the Northern Ireland Human Rights Commission (NIHRC) and the transformation of policing. It addressed some legacy issues in relation to victims/survivors and political prisoners, but lacked any real detail regarding future accountability or truth telling mechanisms (Bell, 2003; Dawson, 2007). As the various strands of the Agreement took shape and were implemented, the lack of political or societal consensus on ways to address the past has become increasingly apparent. The idea that the society can afford to not deal with the past has been publicly challenged by both non-governmental organisations (NGOs) and official bodies (HTR, 2002; 2006; Rolston, 2002; Eolas Project, 2003; NIHRC, 2003). In the intervening period, the 'top-down' (official) process of dealing with the legacy of past violence has been piecemeal and incremental. It has included a small number of public inquiries and individual cases of litigation, a focus on resourcing support and advocacy services for victims and survivors, and the establishment of a new body in 2005 (the Historical Enquiries Team) to investigate unsolved conflict-related deaths, subsequently suspended due to serious concerns about how cases of state involvement in deaths were addressed, among other issues (HMIC, 2013). More recent attempts to develop a comprehensive framework to address the legacies of the past, including truth recovery processes, have repeatedly fallen foul of the conflictual relationships and ideological differences between the main political parties, and the reluctance of the British and Irish governments to agree to full transparency in relation to their role in the conflict.

A significant challenge to the pursuit of justice and uncovering truth is the inaccessibility of records which might shed light on past atrocities and human rights abuses. Unlike other contexts, where the extensive records held by the former regimes become available posttransition, the likelihood of this happening in Northern Ireland is slim. A recent report by the Committee for the Administration of Justice (CAJ) highlighted the culture of concealment and obstruction in the accessibility of security-related records held by the British state (CAJ, 2015). It also remains unclear the extent to which non-state actors (some of whom are now represented in the political structures) held documentation about the past, and if any such records exist at all. While information about the past bleeds into the present

\footnotetext{
${ }^{5}$ In the Northern Ireland context, the term 'storytelling' is often used interchangeably with oral history or testimony-gathering processes related to the conflict.
} 
through the managed release of historical documents by state archives, ${ }^{6}$ official judicial processes and information publicly disclosed by individuals, this represents an inadequate and fragmented approach to the past (OHCHR, 2015). It is within this context that we aim to chart the surprising number of calls for an oral history archive to be considered as a necessary component of any wider dealing with the past mechanisms to be developed in Northern Ireland.

\section{Official recommendations for a storytelling and archiving process}

In October 1997, the British government established a Commission led by a former head of the civil service Sir Kenneth Bloomfield 'to look at possible ways to recognise the pain and suffering felt by victims of violence' (Bloomfield, 1998: 8). While it made no formal recommendation about a story gathering process, it did refer to 'the cathartic effect of putting one's experience on record' as being 'profound' (1998: 19). Controversially, the report made little mention of victims of state violence, although it did not rule out the possibility of an over-arching truth and reconciliation commission. While a range of community and government processes to support victims unfolded in the immediate postaccord years, political tensions led to the suspension of the Northern Ireland Assembly in 2002 and it was not until 2007 that the first major government-instigated initiative to look at a comprehensive approach to dealing with the past was established by the Secretary of State for Northern Ireland under the New Labour government.

In early 2009, an eight-person Consultative Group on the Past (CGOP) published a detailed report containing $31 \mathrm{key}$ recommendations, including the creation of a Legacy Commission with a wide remit to conduct a process of information recovery, review and investigate historical cases and examine linked or thematic cases emerging from the conflict. Three recommendations specifically related to storytelling and story gathering processes (CGOP, 2009). The report noted that many consultees felt the 'opportunity to place their testimony on record in a permanent archive was important' (CGOP, 2009: 98). However, there was no consensus on where such an archive could be established, although there were suggestions that it form part of a museum collection or be a virtual online archive (CGOP, 2009: 98). While there were proposals that the archive become a public resource 'from which all might learn to acknowledge the perspectives of the other side', others felt it should be private so that the storyteller could control access to their story and sensitive information could be managed (CGOP, 2009: 98). Quickly embroiled in public controversy associated with one particular recommendation concerning compensation payments, the comprehensive nature of the proposals and the likelihood of implementation was deemed to be dead in the water by the following year, and with it the establishment of an oral history archive (HTR, 2013).

However, the idea of establishing a central repository of personal narratives persisted, at least in some political circles. In its 2011 Election Manifesto, the Democratic Unionist Party (DUP) pledged to 'seek to establish an oral and video archive for victims and survivors of the Troubles' (DUP, 2011: 21). This was, however, only one of seven proposals

\footnotetext{
${ }^{6}$ The Public Records Office for Northern Ireland is the official archive for Northern Ireland. Since 2011, official files are released on the basis of a 20 year rule (a 30 year rule applied from 1976 to 2011). Restrictions on the release of public documents apply. See:

www.proni.gov.uk/index/research and records held/annual releases.htm. The National Archives of Ireland, the official holder of records of the Irish modern state, releases documents from their archives every 30 years, with similar restrictions. See: www.nationalarchives.ie/about-us/national-archives $\% \mathrm{E} 2 \% 80 \% 99$-responsibilityfor-archives/responsibility-for-departmental-records/
} 
related to 'the past', which also included the pledge to 'resist attempts by republicans and elements of the media to rewrite the history of the last four decades or justify terrorist campaigns' (DUP, 2011). In another context, a 'large majority' of a working group of the Victims and Survivors Forum, which was established by the Commission for Victims and Survivors to represent the diversity of victims' experiences, and to advocate for them, recommended in 2013 that 'stories should be collected from existing projects and become part of a newly designed story telling project to contribute towards a composite narrative of the past' (Victims Forum WG, 2013: 22).

After a period of intense protest in Belfast starting in late 2012 concerning on the decision of the council to restrict the flying of the Union flag, the five main political parties were forced around the negotiating table in 2013 to reach agreement on flag-flying, contentious marches and the unresolved issue of how to deal with the past. After weeks of intense negotiations, the talks chairs, US Diplomat Richard Haass and academic Meghan O'Sullivan drafted a 'Proposed Agreement'. Among other recommendations, including the establishment of an Historical Investigations Unit (HIU), an Independent Commission for Information Retrieval (ICIR) and an Implementation and Reconciliation Group (IRG), it was proposed to establish 'an archive for conflict-related oral histories, documents and other relevant materials from individuals of all backgrounds, from Northern Ireland and beyond, who wish to share their experiences connected with the conflict' (Panel of Parties, 2013: 36). The five main parties in the Northern Ireland Assembly failed to reach agreement on these proposals and, again, the comprehensive set of recommendations stalled. In 2014, a new political crisis centring on the public welfare cuts proposed by the UK Conservative Government brought the five main political parties in to a new round of negotiations.

The resultant Stormont House Agreement (SHA) reached in December 2014 revived many of the recommendations contained in the Haass and O'Sullivan proposals (albeit with less detail), and again included the provision for the establishment of 'an Oral History Archive to provide a central place for people from all backgrounds (and from throughout the UK and Ireland) to share experiences and narratives related to the Troubles'. It also noted that the archive would be 'independent and free from political interference' (SHA, 2014: 5). In 2015 , the interpretation by some of the political parties of the detail contained within the SHA, and the addition of a new political crisis centred on the alleged involvement of the IRA in the murder of a prominent former IRA member, resulted in a new round of negotiations lasting for ten weeks between September and November. The resultant 'A Fresh Start: Stormont Agreement and Implementation Plan' (Northern Ireland Executive, 2015 ) issued in November 2015 noted that 'it did not prove possible to resolve all of the key issues within the timescale' in relation to dealing with the past and, at the time of writing, it remains unclear if any of the proposals contained in the original SHA will be fully implemented. That being said, work on the establishment of an 'official' oral history archive (OHA) has taken place in the intervening period, with the responsibility for its implementation been assigned to the Public Records Office of Northern Ireland (PRONI), the official government archive established in 1923 and operating as part of a government department, within the Northern Ireland Civil Service.

\section{Community-driven story gathering}

At the same time as the more formal calls for a central space to gather and/or house personal testimonies took shape, an interesting space began to open up in the changing postAgreement landscape in which individuals were supported and encouraged to share their 
personal experiences of the conflict at a community level. Starting tentatively, and later mushrooming, a number of structured, group-based story-sharing processes (outside of the formal therapeutic environment) emerged (Kelly, 2005), alongside dozens of projects and initiatives which began to gather and disseminate audio, audio-visual and written accounts from individuals representing a significant diversity of perspectives.

Empirical research conducted by Kelly in 2004 (Kelly, 2005) and 2013 (Kelly, 2013) indicates that there are, or have been, over 60 organisations (and a small number of individuals), involved in story gathering projects with identifiable, tangible outputs, and that the numbers of stories documented is, at a conservative estimate, at least several thousand (Kelly, 2013). Some of these projects have been relatively modest in ambition, collecting a small number of stories (say 10-20) focusing on a specific issue or event (for example, the cases of the Disappeared, or the Omagh bomb of 1998) (WAVE Trauma Centre, 2012; Spencer, 2005). Others have been more ambitious in scale and financial investment, such as the European Union funded Border Lives audio-visual project which, between 2013 and 2015, collected 90 'everyday' stories of a diverse range of individuals living in the border region between Northern Ireland and the Republic of Ireland edited in to six thirty-minute documentaries ${ }^{7}$ or the Peace Process: Layers of Meaning project, which gathered 100 'heritage interviews' documenting the 'recollections and views of key figures in the peace process', placed under embargo for up to 40 years. ${ }^{8}$

Such was the level of community-based interest and activity in gathering personal narratives, the cross-community, membership-led organisation, Healing through Remembering (HTR), facilitated the creation of a network of interested individuals which sought both to explore the feasibility of establishing a collective oral history process called 'Testimony', a recommendation originally made by HTR in 2002 (HTR, 2002). The network also sought to support the development of community-based processes of story gathering processes, based on sound ethical principles and good practices (HTR, 2009).

Space does not permit a full review of all the testimony work undertaken, the types of stories gathered or the modes of dissemination or archiving. However, some observations can be made about the evolution of this work. While the distinction is not clear-cut, we can identify two broad phases in its development: the first decade post-Agreement (1998-2007) and 2008 onwards. Some of the early work, including the An Crann/The Tree initiative instigated by Damian Gorman in 1995, the Borderlines Project, and the influential Cost of the Troubles research study, sought explicitly to gather and disseminate testimonies from a wide range of individuals to demonstrate the complexity and diversity of experiences of conflict (An Crann/The Tree, 2000; Smyth and Fay, 2000; Borderlines Project, 2006). Other early instigators were new victims/survivors organisations which were established during the mid to late-1990s, many (though not all) representing specific community or political backgrounds, including those affected by either state and non-state violence. A number of these organisations undertook traditional oral history interviews, creating booklets of edited stories, curating small exhibitions, working with local media to publish personal accounts and build dedicated websites. Others utilised non-traditional methods, directly supporting the story 'teller' in the development of remembering quilts, stained glass windows and glass

\footnotetext{
${ }^{7}$ See: www.borderlives.eu

${ }^{8}$ See: www.peaceprocesshistory.org
} 
mosaics ${ }^{9}$, which allowed their stories (or that of loved ones killed) to be visually represented with, in some instances, accompanying texts (WAVE Trauma Centre, 2003).

With the release of political prisoners post-1998, as part of the Belfast Agreement, a number of ex-prisoner support and advocacy organisations undertook modest projects to document the experience of some of those imprisoned. These tended to be predominantly within the republican, rather than loyalist communities, and, with a few exceptions, the stories were initially not widely disseminated. One academic-led audio-visual project gathered 170 testimonies of those who passed through the Maze/Long Kesh and Armagh prisons, including prison staff, politically motivated prisoners, relatives, doctors, probation officers and teachers in 2006-2007, making about one quarter publicly accessible via a dedicated website. $^{10}$

Another significant project focused on the personal accounts of former combatants (both republican and loyalist) is the Belfast Project, which collected oral histories between 2001 and 2006 and archived them (under embargo until the death of the contributor) with the Burns Library at Boston College. When knowledge of the archive's existence went public in 2010 it resulted in ongoing requests by the Police Service of Northern Ireland, investigating conflict-related deaths, to obtain copies of the recordings. While space does not permit a full analysis of this complicated case (George, 2013; King, 2014; O'Donnell, 2012) it serves to highlight how oral histories (even those with restricted access) maintain the potential to impact on judicial processes and become spaces for on-going political contestation.

While the majority of the non-official initiatives have been community-led, several others were also instigated by, or involved, academics working in partnership with organisations or individuals to gather and disseminate personal accounts as stand-alone outputs, most typically in book format (Ardoyne Commemoration Project, 2002; Rolston, 2000; Rolston, 2011; Smyth and Fay, 2000; Spencer, 2005). In addition, a number of individuals gathered personal accounts, including the experience of British soldiers who served in Northern Ireland (Lindsay, 1998; Wharton, 1998) and those bereaved at the hands of paramilitaries on both sides (Wilson, 2005). As a public broadcaster, the regional station of the BBC, Radio Ulster, instigated a year-long series entitled 'Legacy' in 1999. Introduced at 8.58am each morning two-minute extracts of longer interviews conducted by the production team were aired, with many of the story tellers not identified by name in the edited piece.

During this early period (1998-2007), two oral history projects with an explicit focus on the establishment of physically accessible sound and transcript archives were also instigated. The first was the Falls Community Council's Dúchas (meaning heritage) archive, which gathered stories from the mainly nationalist, working class West Belfast area (Hackett, 2003). The second focusing on the experiences of police who worked within the Royal Ulster Constabulary between 1922-2001 during the conflict. ${ }^{11}$ Both archives continue to be developed and maintained to the present day.

Financial support for this early work varied, with the costs of some projects being met by resources targeted at victims/survivors organisations or funders with a more specific cross-

\footnotetext{
${ }^{9}$ See: http://relativesforjustice.com/services/remembering-quilt/ and www.wavetraumacentre.org.uk/aboutus/wave-projects

${ }^{10}$ See: prisonsmemoryarchive.com

${ }^{11}$ See: www.rucgefoundation.org/oral-history/
} 
community or reconciliation agenda, while a small number of independent donors supported the more advocacy-type projects. However, the context for story gathering work changed significantly post-2007 with the prioritisation of story gathering work by the European Union's Peace and Reconciliation Programme during their 2007-2013 funding cycle period. ${ }^{12}$ The programme allocated 50 million euro of grant aid to a thematic focus on 'acknowledging and dealing with the past', with one of three sub-strands dedicated to 'addressing the past in public memory' (Deloitte, 2010). Under this broad banner, a raft of new storytelling or oral history work was supported. These projects tended to be more ambitious in scale and reach than previously (and thus more costly), with some involving the development of complex and challenging partnerships of constituency groups. For example, through the Dúchas archive, a new partnership was formed with community organisations across Belfast, representing both unionist and nationalist communities. Oral history interviews were gather from across the traditional divisions and placed together in an archive, with extracts published in a book (Pieces of the Past, 2014).

In another context, and building on working relationships established between a range of politically motivated ex-prisoner groups from across the political spectrum established the Prison to Peace Partnership to explore a wide range of conflict transformation and social change issues. As part of the consortium's work, thirty interviews with former combatants were conducted to explore individual motivations for involvement, reflections on the conflict and experiences of imprisonment, and a collection of anonymised extracts were subsequently published (Community Foundation for Northern Ireland, 2014). Another project sought, for the first time, to document, and place together, the experiences of former members of the Royal Ulster Constabulary and their Irish counterparts, An Garda Síochána, coupling this with wider relationship-building work (Diversity Challenges, 2014).

Of the newly funded projects, there was also a greater focus on innovative modes of dissemination, including theatre-based work, which gathered and utilised testimonies of individuals to develop fictionalised dramas focusing on issues, including policing, victimhood and mixed marriage. Educational materials and facilitated workshops reaching in to a wide range of communities were also developed which utilised the personal stories as a catalyst for encouraging dialogue between groups from different political perspectives (The Corrymeela Community and Facing History and Ourselves, 2013; Emerson et al., 2014).

A feature of all this community-based testimony and oral history work is the different methodological approaches used in the gathering of the stories, and the diverse thematic issues explored. While one would expect issues of bereavement, grief, loss, injustice and incarceration in a society emerging from violent conflict, projects have also focused on themes of courage (The Corrymeela Community and Facing History and Ourselves, 2013), nursing during times of conflict (Graham and Orr, 2013), mixed marriage (Northern Ireland Mixed Marriage Association, 2012) and membership of the Orange Order (Minto, 2013), among others.

\section{Accounts of the Conflict: A hybrid model of archiving?}

While there were notable exceptions, a key finding from Kelly's (2005) research was the lack of consideration given to the long-term preservation and archiving of materials

\footnotetext{
${ }^{12}$ See: www.seupb.eu/programmes2007-2013/peaceiiiprogramme/overview.aspx
} 
gathered by community-based organisations. This was due, in part, to the short-term nature of funding, but also to an absence of consideration as to the long-term value in preserving the stories (particularly the unedited, longer versions) for future usage beyond the development of a specific product, such as a book or film. With the rise in digital recordings, the research highlighted additional concerns regarding the storage capacity required, and the possibility of hardware and software obsolescence which could render recordings inaccessible over time (Kelly, 2005).

In response to these preservation-related challenges, along with a team of colleagues at Ulster University, the authors have been involved in the development and establishment of a web-based, fully accessible, oral history archive called Accounts of the Conflict, ${ }^{13}$ envisaged as a central digital repository for existing and future story gathering projects. The purpose of the archive, funded by the EU Peace and Reconciliation Programme, was not to directly collect testimonies and is best described as a 'collection of collections', albeit with the potential for individuals to submit their own written or recorded testimonies outside of more formal story gathering projects, subject to certain conditions being met. The initial scope of the project was to develop the infrastructure to create the digital archive, and to engage with community-based organisations to gain their trust and confidence to deposit the full or edited versions of the stories, in audio, audio-visual or transcript/written formats, into the archive. In addition, the Accounts archive also sought to catalogue information on all oral histories that are in the public domain but not deposited with Accounts, as a resource for those interested in conducting further research and analysis, as well as to highlight the breadth and depth of material currently gathered.

The placing of disparate stories in one central space obviously raises a set of issues, which are practical, ethical, emotional and political in nature. At the time of writing Accounts of the Conflict remains the most substantive central repository of testimonies of the Northern Ireland conflict, as Gorman had previously proposed. Nevertheless, it is still in the nascent stages of development, and has yet to reach its potential in terms of multiple societal use.

\section{Contested Narratives: Lessons from Northern Ireland}

Despite the financial investment and levels of activity focused on the collection of oral histories related to the Northern Ireland conflict, a key question remains: how socially transformative can an oral history be as a core way of addressing the past at a societal level and in challenging or altering entrenched historical narratives? In the final section, we will explore how the process of story gathering has been limited as a result of the contested nature of politics and competing narratives in the post-accord context. Thereafter we will explore what this means for the prospects of an official archive being firmly established and maintained in the Northern Ireland context, and its relationship to community-based initiatives.

\section{The struggle for a hegemonic narrative at the official level}

In the Northern Ireland context, it is commonplace for political parties to publicly accuse each other of presenting a biased view of the past. Typically, republicans are accused of trying to 'rewrite' history to justify paramilitary violence by those of a unionist persuasion, and the British State and unionists are accused of hiding their hand in a 'dirty war' and

\footnotetext{
${ }^{13}$ See: www.ulster.ac.uk/accounts
} 
committing human rights violations and social exclusion against ordinary (mainly Catholic) citizens. Within the political sphere, the contention that particular communities' lived experiences have been marginalised is frequently expressed. This is starkest in the debate as to who is a 'legitimate' victim and where some contend that there is a hierarchy of victimhood (Breen-Smyth, 2009). In short, although many community-based storytelling initiatives articulate a desire to bridge gaps and share accounts of the past as a way of promoting individual healing, mutual humanization and community reconciliation, in public debate the use of selective narratives in which the victim label applies to 'us' and not to 'them' is commonplace (Hearty, 2014).

If we accept the definition of hegemonic narratives as 'overpowering, dominant stories that encounter little societal opposition' (Subotić, 2013: 307), then no narrative is completely hegemonic in the Northern Ireland context and all encounter substantial opposition. Some might argue that there is a hierarchy of narratives with the British state having been and remaining the most powerful over time. However, on a day-to-day basis and in terms of popular public discourse, it is difficult to sustain an argument that one narrative completely dominates the other, or deprives alternative narratives from the 'possibility of winning arguments' (Subotić, 2013: 308). In this sense, the struggle in Northern Ireland is one of dominant, subordinate and marginal narratives across the spectrum, not only between individuals and the British and Irish states, but between and within communities as well. Put another way, the society, despite its significant progress toward peace, is still characterised by a struggle between a series of contesting narratives, supported in the public domain by opposing political parties, vying to become the hegemonic narrative.

Overall, this makes the prospect of an acceptable 'official' process of recording and centrally archiving testimonies within a state-funded institution incredibly challenging. As noted above, initiatives like Accounts of the Conflict, which has no official mandate, have begun the process of preserving existing stories collected by the community sector. To date, this has been achieved through the seeking of explicit, informed consent of the individual storyteller to have their testimony included in the archive. The challenges facing a government-sponsored, 'official' archive, which would include the gathering of new testimonies as part of its remit, will be significantly more daunting, and the contribution of the community work previously undertaken in any emerging 'official' process remains unclear.

\section{Prospects for an official oral history archive}

As evidenced in the initial endorsement of the SHA by the main political parties in Northern Ireland, one can identify a gradual willingness or 'thin' consensus (Hearty, 2014) to acknowledge that a diversity of narratives about the past exists and that these could sit alongside one another in one centralized space. However, simultaneously, there appears to be little willingness by the parties to alter their macro perspective on the nature of the conflict. Both authors have been involved in discussions with local politicians as to the mechanics of establishing an official oral history archive and the practical and ethical issues to be considered. Almost routinely, a primary concern is how to ensure that no one narrative should dominant the archive and that efforts be made to ensure 'balance' in terms of both the number and types of stories gathered or deposited in the archive.

The previous recommendation in the Haass-O'Sullivan document (Panel of Parties, 2013) for an archive for conflict-related oral histories noted that the archive would 'not seek to interpret 
people's narratives or attempt to create any single narrative of the past' (Panel of Parties, 2013: 36). In the latest summary of measures for a potential bill to establish the Archive (NIO, 2015) it is once again clear that the process is not about establishing one truth about the past. Rather it is acknowledged that 'Oral history can provide a means of recording alternative narratives, adding layers of meaning to existing accounts, or challenging preconceptions' and is a necessarily subjective process and 'the person collecting the oral history will not test the veracity of the content but allow the contributor to record their perspective' (NIO, 2015: 30). In a tightly contested political terrain, this is understandable. Conventional practice in the gathering of oral histories or personal testimonies is also to accept, rather than challenge the individuals' subjective memories of the past.

However, concerns with subjectivity extend beyond oral history practice, and at the political level, they are about how, and if, information from testimonies will challenge existing narratives of the past. This is demonstrated by the fact that none of the various processes for uncovering the truth about the past (SHA, 2014; NIO, 2015) are referred to or considered as a 'truth commission', which in name alone might imply a more definitive outcome. While the proposals contained in the SHA did allow for the extraction of themes from the various measures to be established (including the HIU, OHA and the ICIR), they did not convey the same sentiments seen in other dealing with the past processes globally, such as labelling corporate or institutional responsibility or apportioning collective culpability for past violations. Seen in this light, there is a risk that competing memories of the past are being 'reconciled' by creating 'parity at any price' (Barkan, 2009: 910). This raises questions about how issues of responsibility, justice and guilt are really being dealt with (Barkan, 2009), if at all. In other words, the political parties may have accepted the unlikelihood that their narrative will ever become entirely hegemonic and have settled for an approach in which different narratives can sit side-by-side in the hope that their version will slowly win space over another. Or, if this does not transpire, at least their particular narrative will be tolerated and acknowledged by others. Such an approach, although seemingly positive on the surface, can be a way of closing down discussions about the past, by expressing respect, if not acceptance, of others' differing experiences and perspectives. Hearty refers to this as the repackaging of old selective narratives as 'shared' whilst continuing to perpetuate understandings of the past that are oblivious to the reality of the 'other' (Hearty, 2014).

If an official oral history archive were it to be established, it is possible, however, that it would have some discernible effect on the wider society, albeit the extent of which is still unknown. Despite the challenges outlined above, there is potential in creating a sanctioned oral history archive that would act as a vehicle for different narratives to interact and affect change. This, however, would require an active process of encouraging interaction with the contents of the archive and dissemination processes that can reach a wide (and receptive) audience. If established with the principle of ensuring public accessibility, the new archive could indeed challenge 'preconceptions' (NIO, 2015). A feature of a divided society such as Northern Ireland is the limited opportunities that exist for people to share their diverse (and often divergent or opposing) experiences of the conflict in person. An oral history archive could provide such an opportunity, albeit at one distance removed from the individual 'teller' (via recordings, transcripts or other creative media) if designed successfully. In this context, it seems evitable that, as stories are made more accessible, the potential to challenge existing discourses opens up - never more so than in the context of the new social media tools which are particularly reactive, have an extensive and diverse reach, and are largely unregulated. As Elizabeth Jelin (2007) observes in the context of a range of physical commemorative processes (and we would say equally about archives), revisions and 
changes in narratives, and new conflicts over interpretation will inevitably arise over time (149).

Challenging preconceptions could take place through receiving and accepting of personal accounts that do not fit one's own historical narrative of past events. In the South African Truth and Reconciliation Commission, for example, a number of cases presented (such as where the ANC killed young boys because they believed they were spies, or the apartheid state security services planted bombs and blamed the ANC) challenged the comfortable picture which some had of the political groups or factions that they supported; that is, that those they supported were all good and that their enemies were consistently evil (Hamber, 2009). Of course, one cannot predict exactly how political parties might react to new and challenging interpretations of the past if they emerge, and the references to the 'subjective' nature of oral histories and that their content will not be tested for 'veracity' (NIO, 2015: 30) suggests the possibility that particularly challenging narratives could be publicly questioned or dismissed. Given the contested nature of the past, it is hard to imagine how an official, publicly funded, archive can, therefore, remain entirely free from political interference as the SHA advocates (see Bryson, 2015 who also makes this point), particularly if opposing groups feel the archive is beginning to challenge their version of the past too vigorously.

If the official archive goes ahead, the archive itself could be limited in other ways too. Firstly, with a focus on collecting personal 'subjective' narratives outside of a wider structure (such a truth commission with a mandate of exploring the causes of the conflict) there is a risk the process will become entirely individualized and detached from the broader political context. This fits with the recent observation by the Special Rapporteur on the Promotion of Truth, Justice, Reparation and Guarantees of Non-recurrence that the dealing with the past process in Northern Ireland seems to be overly focused on individual cases rather than wider contextual issues (OCHRC, 2015). Likewise Kelly's empirical research $(2005 ; 2013)$ indicates that motivations for story gathering projects at community level have been surprisingly varied but largely individually focused, including: healing or therapeutic benefits for the narrator; contributing to the historical record; acknowledging and commemorating the lives of loved one's lost; engaging and informing a wider audience (particularly the younger generation) of the complexity and impact of conflict at individual level. While some initiatives were more explicitly focused on justice, advocacy and wider community experiences of the conflict, arguably these represented the minority approach. We contend that the focus on the individual may, at least in part be a reflection of the nature of the funding to the sector in Northern Ireland, which has emphasized people-to-people peacebuilding work (Cochrane and Dunn, 2002; Belloni, 2010) with a particular 'reconciliatory' focus, rather than the potential for such community-based processes to be uncomfortable and confrontational in nature, especially at the 'official' level.

Secondly, although arguably anyone could bring their story forward, challenging and hardhitting narratives of the conflict (such as those of collusion, sexual violence, organised criminality and corruption or intra-community killings) could be under-emphasised, as has already happened with publicly funded community-based initiatives where such narratives have seldom been the focus of testimony gathering work. This may be because of the predominantly public nature of the majority of the testimonies gathered (unlike the Belfast Project mentioned above), the thematic, sectoral or geographical focus of specific projects, and the stringent legal ramifications of both self-incrimination and defamation in the UK and Ireland which curtail both the story gatherer and story teller from exploring particular 
aspects of the conflict.

Finally, it has been questioned whether locating the new 'official' archive within the traditional government records keeping agency, given its stated policy of risk aversion and excessively bureaucratic and legalistic approach, would lead to anything other than 'an anodyne repository of 'safe' and unchallenging narratives' (Bryson, 2015). This raises questions about the governance of the process, and how much influence external parties might have in guiding the development of the archive and how flexible it can be in its testimony gathering process.

\section{Conclusion: Emerging lessons for other societies}

The Northern Ireland case can add a great deal to the international debate on the development of testimony-based archives in post-conflict societies. In many contexts (classically the South Africa post-apartheid case), the hegemonic narrative was challenged during and after transition, and testimony work was directly related to the public disclosure of human rights violations and efforts to ensure non-repetition. However, Northern Ireland reminds us there are many contexts in which it is not simply a contestation between hegemonic and counter-hegemonic narratives at a vertical level (which of course exist), but also about ongoing and evolving contestations between, and within, communities at a horizontal level. The possibility that this will become a destabilizing influence or fertile ground for further conflict is ever present.

However, it is also possible that, in the context of a peace process where power remains contested but where relative peace and advancements in the protection of human rights has been achieved, a process of co-existence and toleration of other narratives can emerge. In such a circumstance, a number of questions therefore arise: what happens if a 'balance' of narratives is not met (or seen to be met), or if narratives emerge that challenge long held 'truths'? Will politicians 'interfere' by publicly withdrawing support for the idea, reducing funding or encouraging their constituencies not to engage with the process? Or will an bland process emerge which may not initially be politically transformative at the macro level and only focus on individual and micro community perspectives of the past (as in the way community-based storytelling work emerged in Northern Ireland), but equally have the ability to evolve and change?

International experience indicates that testimony gathering and the development of archives have a life of their own, once established (Schaffer and Smith, 2004; Subotić, 2013). In Northern Ireland, the persistence of calls for an 'official' 'official' process of sharing narratives suggests there is some confidence in such process making an individual, and ultimately societal, different. Those of us involved in the Accounts of the Conflict project often assert that its value is in allowing the multiple narratives (gathered at community level) to be placed alongside one another, in all their diversity, contradiction and complexity, and that those narratives are, or have the potential to be, widely disseminated. In this context, the glimmers of hope for an 'official' archive, especially in a society where macro historical narratives have appeared to stagnate, lies in what it might inadvertently unleash and how this might interact with the community-based oral history work already taking place.

This process has its limits and risks in a context such as Northern Ireland as noted. Currently it is difficult to see beyond a version of the past which is trapped in a cycle of counter- 
balancing one narrative against another in an effort to ensure no hegemonic narrative emerges or uncomfortable truths are exposed. From a human rights perspective, it also means that the issues of guilt and justice, as Barkan (2009) warns, may not easily be addressed. However, equally, and notwithstanding the challenges outlined above, an 'official' archive also holds the potential to deal with neglected themes such as gender and class (Bryson, 2015). This will depend on how the process is handled (such as the breadth and wording of the call to participate in giving testimony; questions asked by the testimonytakers; how independent or open the process is is perceived by the public and the breadth of dissemination), as well as the nature and level of interaction with community archives.

Supplementing the 'official' process with wider testimony gathering processes directed by, and located within community contexts, is imperative. Such unofficial processes have been found to be complementary to 'official' processes globally, albeit that the relationship between 'the official' and the unofficial testimony gathering processes might not be 'friendly', and may disagree and be competitive (Bickford, 2007: 1005). The experiences and knowledge gained by bottom-up community testimony processes in Northern Ireland therefore needs to be placed centrally in the development of any official oral history archive, while also ensuring that they retain a challenge function to counter the bureaucratic tendencies to standardize and regulate what can be a deeply emotional and highly political act. This will rely on a highly dynamic and reflexive civil society that is willing and able to engage consistently in the dealing with the past debates and processes with an impartial guiding set of human rights principles that are not swayed by allegiance to different narratives or political views. Such unofficial processes will have to be challenged to stretch beyond collecting testimony on the 'comfortable' issues that fit with dominant historical narratives. The deliberate juxtaposition of contrasting horizontal or inter-community narratives held by different local parties may allow for the emergence of a more complex and inclusive narrative of the past, rather than attempts to impose a shared vertical narrative, which is subject to either further contestation or uncomfortable compromise.

For any society emerging from conflict, the Northern Ireland case highlights the value in framing a peace process in such a way that is can facilitate, at a bare minimum, a mutual respect for competing narratives. This can be supported by the emergence of new political discourses, as well as institutional and legislative frameworks focused on human rights or equality. However, it should also be underpinned by significant investment in communitybased, people-to-people processes, highlighting the value of what has been termed the civil society, cultural and personal aspects of the non-recurrence agenda in transitional justice (UN Human Rights Council, 2015). Such an approach has its pitfalls as this article has outlined, and it lacks the clarity of a strictly justice driven human rights approach, but slow progress is being made in Northern Ireland despite the persistence of profound and contested views of the past. However, much work remains to develop a 'living' official archive that positively interacts with unofficial processes and can jointly challenge long held and entrenched historical narratives across the society. 


\section{References}

An Crann/The Tree 2000. Bear in Mind: Stories of the Troubles. Belfast: Lagan Press.

Ardoyne Commemoration Project 2002. Ardoyne: The Untold Truth, Belfast: Beyond the Pale.

Barkan, E. 2009. 'Introduction: Historians and Historical Reconciliation'. The American Historical Review 114(4): 899-913.

Bar-Tal, D., Oren, N. \& Nets-Zehngut, R. 2014. 'Sociopsychological analysis of conflictsupporting narratives: A general framework'. Journal of Peace Research, 51(5): 662675.

BBC 2008. Legacy: A collection of personal testimonies from people affected by the Troubles in Northern Ireland. Belfast: British Broadcasting Corporation Northern Ireland.

Bell, C. 2003. 'Dealing with the Past in Northern Ireland'. Fordham International Law Journal, 26(4): 1095-1147.

Belloni, R. 2010. 'Northern Ireland: civil society and the slow building of peace'. In Paffenholz, T. (ed.) Civil society \& Peacebuilding: A Critical Assessment. London: Lynne Rienner.

Bickford, L. 2007. Unofficial Truth Projects. Human Rights Quarterly, 29(4): 994-1035.

Bloomfield, K. 1998. We will remember them. Report of the Northern Ireland Victims Commissioner. Belfast, Stationery Office.

Bryson, A. 2015. The Stormont House Oral History Archive, PRONI, and the Meaning of Independence. Guest post 2 October. Belfast: Rights NI at http://rightsni.org/2015/10/the-stormont-house-oral-history-archive-proni-and-themeaning-of-independence-guest-post-by-dr-anna-bryson/

Borderlines Project 2006. Borderlines: personal stories and experiences from the border countries, Dublin: Gallery of Photography.

Brown, K. \& Ní Aoláin, F. 2014. 'Through the Looking Glass: Transitional Justice Futures through the Lens of Nationalism, Feminism and Transformative Change'. International Journal of Transitional Justice.

CAJ 2015. No Apparatus of Impunity? Human Rights Violations and the Northern Ireland Conflict: a narrative of official limitations on post-Agreement investigative mechanisms. Belfast: Committee for the Administration of Justice

Cardenas, S. 2010. Human Rights in Latin America: A Politics of Terror and Hope, Philadelphia, PA: University of Pennsylvania Press.

CGOP 2009. Report of the Consultative Group of the Past, Belfast: Consultative Group on the Past.

Chapman, A. R. \& Ball, P. 2007. 'Levels of Truth: Macro-Truth and the TRC'. In Chapman, A. R. \& van der Merwe, H. (eds.) Truth and Reconciliation in South Africa: Did the TRC Deliver? Philadelphia, Pennsylvania: University of Pennsylvania Press.

Ciorciari, J. D. \& Franzblau, J. M. 2014. 'Hidden Files: Archival Sharing, Accountability, and the Right to the Truth'. Columbia Human Rights Law Review, 46(1): Available at SSRN: http://ssrn.com/abstract=244620.

Cochrane, F. \& Dunn, S. 2002. People power? The role of the voluntary and community sector in the Northern Ireland conflict, Cork: Cork University Press.

Community Foundation for Northern Ireland 2014. Reflections: From conflict to prison, and from prison to peace, Belfast: Ogham Press.

Dawson, G. (2007). Making peace with the past? Memory, trauma and the Irish troubles. Manchester: Manchester University Press. 
Deloitte 2010. Theme 1.2 Acknowledging and Dealing with the Past, Review of Implementation Report. Belfast: SEUPB.

Diversity Challenges 2014. Green and Blue Across the Thin Line, Armagh: Diversity Challenges.

DUP 2011. Moving Forward Manifesto 2011. Belfast: Democratic Unionist Party.

Lesley Emerson, Karen Orr and Paul Connolly (2014). Evaluation of the effectiveness of the 'Prison to Peace: Learning from the experience of political ex-prisoners' educational programme, QUB, Belfast: The Centre for Effective Education.

Eolas Project 2003. Consultation paper on truth and justice: a discussion document. Belfast: Eolas Project c/o Relatives for Justice.

EPIC 2004. Truth Recovery: A Contribution from Within Loyalism. Belfast: EPIC.

Faulkner, L. (2014). Truth Recovery - Revisited: A Contribution from within Loyalism. EPIC \& Intercomm: Belfast.

George, C. 2013. 'Archives Beyond the Pale: Negotiating Legal and Ethical Entanglements after the Belfast Project'. The American Archivist, Spring/Summer, 76(1): 47-67.

Gorman, D. 1994. 1994 Weaving the Future Story. Belfast Telegraph, 17 November.

Graham, M. \& Orr, J. 2013. Nurses' Voices from the Northern Ireland's Troubles, Middlesex: Royal College of Nursing.

Hackett, C. 2003. 'Making History: Duchas, Falls Community Council's Oral History Archive'. Contexts, 2(1): Available at: http://www.communityartsireland.com.

Hackett, C. \& Rolston, B. 2009. 'The burden of memory: Victims, storytelling and resistance in Northern Ireland'. Memory Studies, 2(3): 355-376.

Hamber, B. 2009. Transforming Societies After Political Violence: Truth, Reconciliation and Mental Health, New York: Springer.

Hamber, B. 2015. Dealing with Painful Memories and Violent Pasts: Towards a Framework for Contextual Understanding. In: Austin, B. \& Fischer, M. (eds.) Berghof Dialogue Series 11. Berlin: Berghof Centre.

Harris, V. 2002. 'The archival sliver: Power, memory, and archives in South Africa'. Archival Science, 2(1-2): 63-86.

Harris, V. 2007. Archives and Justice: A South African Perspective, Chicago: Society of American Archivists.

Hearty, K. 2014. 'A Shared Narrative?: A Case Study of the Contested Legacy of Policing in the North of Ireland'. British Journal of Criminology, 54(6): 1047-1066.

HMIC 2013. Inspection of the Police Service of Northern Ireland Historical Enquiries Team. London: Her Majesty's Inspectorate of Constabulary.

HTR 2002. Report of the Healing Through Remembering Project. Belfast: Healing Through Remembering.

HTR 2006. Making Peace with the Past: Options for truth recovery regarding the conflict in and about Northern Ireland written by Kieran McEvoy. Belfast: Healing Through Remembering.

HTR 2009. Ethical Principles - Storytelling and Narrative Work. Belfast: Healing through Remembering.

HTR 2013. Dealing with the Past? An Overview of the Legal and Political Approaches Related to the Conflict in and about Northern Ireland. Belfast: Healing through Remembering.

Humphrey, M. 2002. The politics of atrocity and reconciliation: from terror to trauma, London; New York: Routledge.

Jelin, E. 1994. 'The Politics of Memory: The Human Rights Movement and Construction of Democracy in Argentina'. Latin American Perspectives, 21(2): 38-58. 
Jelin, E. 2007. 'Public Memorialization in Perspective: Truth, Justice and Memory of Past Repression in the Southern Cone of South America'. IJTJ, 1(1): 138-156.

Jones, B. \& Rubli, S. 2013. Archives for a Peaceful Future, Bern: swisspeace.

Kelly, G. 2005. Storytelling Audit: An audit of personal story, narrative and testimony initiatives related to the conflict in and about Northern Ireland. Belfast: Healing Through Remembering.

Kelly, G. 2013. Accounts of the Conflict: A Scoping Study, [Unpublished internal report]. Ulster University: INCORE.

King, J. A. 2014. 'Say nothing': silenced records and the Boston College subpoenas'. Archives and Records, 35(1): 28-42.

Lindsay, J. 1998. Brits Speak Out: British Soldiers' Impressions of the Northern Ireland Conflict, Derry: Guildhall Press.

Lundy, P. \& McGovern, M. 2004. "'You understand again": testimony and post-conflict transition in the Northe of Ireland, The Ardoyne Commemoration Project 1998-2002'. Words and Silences: Journal of the International Oral History Association, 2(2): 3035.

Lundy, P. \& McGovern, M. 2008. 'Whose Justice? Rethinking Transitional Justice from the Bottom Up'. Journal of Law and Society, 35(2): 265-292.

Mamdani, M. 2000. A Diminished Truth. After the TRC: reflections on truth and reconciliation in South Africa. W. James and L. Van der Vijver. Cape Town, David Philip: 58-61.

McLaughlin, C. 2014. Where politicians fail, storytellers address the Troubles in Northern Ireland. Queens Corner [Online]. [Accessed 14 February 2015].

Minto, S. (ed.) 2013. The Forgotten People of Ulster: Stories of Orangeism South of the Border, Kesh: CADELMO.

Northern Ireland Executive. 2015. A Fresh Start - The Storming Agreement and Implementation Plan: An agreement to consolidate the peace, secure stability, enable progress and offer hope. Belfast: Northern Ireland Executive.

NIO. 2015. Northern Ireland (Stormont House Agreement) Bill 2015. Summary of measures. Belfast: Northern Ireland Office, September.

Nolan, P. 2014. Northern Ireland Peace Monitoring Report: Number Three. Belfast: Community Relations Council.

NIHRC. 2003. Human Rights and Victims of Violence Belfast: Northern Ireland Human Rights Commission.

Northern Ireland Mixed Marriage Association 2012. Mixed Emotions: Real Stories of Mixed Marriage, Belfast: NIMMA.

Novick, P. 2001. The Holocaust and collective memory. Great Britain: Bloomsbury.

O'Donnell, R. 2012. 'Oral history and the politics of the Troubles: The Boston College Tapes'. History Ireland, 20(2).

OHCHR. 2015. Preliminary observations and recommendations by the Special Rapporteur on his visit to the United Kingdom of Great Britain and Northern Ireland. The Office of the United Nations High Commissioner for Human Rights (OHCHR): London, 18 November 2015.

Panel of Parties 2013. Proposed Agreement, 31 December 2013: An Agreement Among the Parties of the Northern Ireland Executive, (Haass O'Sullivan Talks, Proposed Agreement). Belfast: The Panel of Parties in the NI Executive, OFMdFM.

Pieces of the Past 2014. Living through the Conflict: Belfast Oral Histories, Belfast: Dúchas Oral History Archive.

Riaño-Alcalá, P. \& Baines, E. 2011. 'The Archive in the Witness: Documentation in Settings of Chronic Insecurity'. International Journal of Transitional Justice, 5(3): 412-433. 
Rolston, B. 2000. Unfinished Business: State Killings and the Quest for Truth, Belfast: Beyond the Pale Press.

Rolston, B. 2002. 'Assembling the jigsaw: truth, justice and transition in the North of Ireland'. Race and Class, 44(1): 87-106.

Rolston, B. 2011. Children of the Revolution: The Lives of Sons and Daughters of Activists in Northern Ireland, Derry: Guildhall Press.

Ross, F. C. 2003. On having Voice and Being Heard: Some after-Effects of Testifying Before the South African Truth and Reconciliation Commission. Anthropological Theory 3(3): 325-341.

Ross, Marc Howard. 2003. Competing Narratives and Escalation in Ethnic Conflicts: the Case of the Holy Sites in Jerusalem. Sphera Pública, 3, Publicación Anual, Universidad Católica San Antonio de Murcia: Murcia, España: 189-208.

Schaffer, K. \& Smith, S. 2004. 'Conjunctions: Life Narratives in the Field of Human Rights'. Biography 27(1): 1-24.

Schwartz, J. M. \& Cook, T. 2002. 'Archives, Records, and Power: The Making of Modern Memory'. Archival Science, 21-19.

SHA 2014. Stormont House Agreement, Belfast: Northern Ireland Office.

Breen-Smyth, M. (2009). Hierarchies of Pain and Responsibility: Victims and War by Other Means in Northern Ireland. Trípodos, 25, 27-40.

Smyth, M. \& Fay, M.-T. (eds.) 2000. Personal Accounts from Northern Ireland's Troubles: Public Conflict, Private Loss, London: Pluto Press.

Spencer, G. 2005. Omagh: Voices of Loss, Belfast: Appletree Press.

Subotić, J. 2013. 'Stories States Tell: Identity, Narrative, and Human Rights in the Balkans'. Slavic Review, 72(2): 306-326.

The Corrymeela Community and Facing History and Ourselves 2013. Up Standing: Stories of courage from Northern Ireland, Belfast: The Corrymeela Community.

Thomas, L. M. 1999. Suffering as a moral beacon: Blacks and Jews. In H. Flanzbaum(Ed.), The Americanization of the Holocaust. Baltimore: Johns Hopkins University.Press: $198-210$.

UN Human Rights Council. 2015. Report of the Special Rapporteur on the promotion of truth, justice, reparation and guarantees of non-recurrence, Pablo de Greiff. A/HRC/30/42. Geneva: United Nations, General Assembly, Human Rights Council Thirtieth session.

Victims Forum WG 2013. Advice Paper to the Commission on Dealing with the Past. Belfast: The Victims and Survivors Forum Dealing With the Past Working Group.

WAVE Trauma Centre 2003. Ballymoney Stained Glass. Ballymoney: WAVE Trauma Centre

WAVE Trauma Centre 2012. The Disappeared of Northern Ireland's 'Troubles'. Belfast: WAVE Trauma Centre.

Weine, S. 2006. Testimony after catastrophe: Narrating the traumas of political violence. Evanston, IL: Northwestern University Press.

Wharton, K. 1998. A Long, Long War: Voices from the British Army in Northern Ireland, 1969-1998, Solihull: Helion and Company.

Wilson, A. 2005. If Stones Could Speak, Belfast: Ambassador Press. .

Wilson, R. A. 2001. The Politics of Truth and Reconciliation in South Africa: legitimising the post-apartheid state, Cambridge: Cambridge University Press. 